\title{
PART II: OPTIMIZATION OF ISOSORBIDE DINITRATE SUSTAINED RELEASE LAYER IN ANTIHYPERTENSIVE BILAYER TABLET
}

\author{
HARSH TRIVEDI ${ }^{*}$, KUNAL PATEL ${ }^{2}$, NISHANT A. OZA ${ }^{3}$, SWATI SAGAR ${ }^{4}$
}

\author{
1,2Shree Swaminarayan Sanskar Pharmacy College, Zundal, Gandhinagar, Gujarat, India, ${ }^{3,4}$ C. U. Shah University, Wadhwan City, Gujarat, \\ India 363030 \\ Email: harshtrivedi28@gmail.com
}

Received: 30 Apr 2020, Revised and Accepted: 06 Jul 2020

\begin{abstract}
Objective: Aim of the present study was the optimization of the sustained release (SR) layer of isosorbide dinitrate (ISDN) 40 mg and compressed with the immediate-release (IR) layer of hydralazine hydrochloride (HHC) $25 \mathrm{mg}$ to decrease the dosing frequency and development of a novel b. i. d dosage form.

Methods: Drug excipients compatibility study was carried out by FT-IR and a preliminary study was conducted for screening of polymer. The amount of HPMC K100M $\left(\mathrm{X}_{1}\right)$ and the amount of Polyox ${ }^{\mathrm{tm}}$ WSR303 $\left(\mathrm{X}_{2}\right)$ were chosen as independent variables in $3^{2}$ full factorial designs. While \% cumulative drug releases at $1 \mathrm{~h}\left(\mathrm{Q}_{1}\right)\left(\mathrm{Y}_{1}\right), \%$ cumulative drug release at $2 \mathrm{~h}\left(\mathrm{Q}_{2}\right)\left(\mathrm{Y}_{2}\right)$, \% cumulative drug release at $4 \mathrm{~h}\left(\mathrm{Q}_{4}\right)\left(\mathrm{Y}_{3}\right)$ and \% cumulative drug release at $6 \mathrm{~h}\left(\mathrm{Q}_{6}\right)\left(\mathrm{Y}_{4}\right)$, were taken as dependent variables and statistically evaluation by using sigma plot 13.0. In the present study, according to the U. S. P. 2007 the following constraints were used for the selection of an optimized batch: $Q_{1}=15 \%$ to $30 \%, Q_{2}=50 \%$ to $70 \%, Q_{4}=65 \%$ to $85 \%$ and $\mathrm{Q}_{6}>75 \%$. To validate the evolved mathematical models, a checkpoint batch was selected from its desirability value.
\end{abstract}

Results: FT-IR spectra show that the drug and excipients were compatible with each other. The calculated F values found for $\mathrm{Q}_{1}, \mathrm{Q}_{2}, \mathrm{Q}_{4}$, and $\mathrm{Q}_{6} \mathrm{~W}_{\mathrm{f}} \mathrm{re}$ 084.583, 038.188, 057.719, and 118.396, respectively. All Calculated F values are greater than the tabulated value for all dependent variables. Prepared checkpoint batch selected from its desirability value 1 and it gives a $93.40 \pm 1.29 \%$ drug release within $6 \mathrm{~h}$.

Conclusion: This bilayer formulation of anti-hypertensive drugs decreases the dosing frequency of HHC and ISDN.

Keywords: Bilayer tablet, $3^{2}$ Full factorial design, Hydralazine hydrochloride, Isosorbide dinitrate, Sustained release layer

(C) 2020 The Authors. Published by Innovare Academic Sciences Pvt Ltd. This is an open access article under the CC BY license (http://creativecommons.org/licenses/by/4.0/) DOI: http://dx.doi.org/10.22159/ijap.2020v12i5.38098. Journal homepage: https://innovareacademics.in/journals/index.php/ijap

\section{INTRODUCTION}

Hypertension affects around half of the adult population worldwide, being one of the most common cardiovascular disorders (CVD). It occurs when the high cardiac output exerts pressure on the arterial wall as the blood flow increases. The conventional dosage form used in the treatment of hypertension cannot produce the desired therapeutic effect for a prolonged period and thus dose fluctuation and missing dose chances are more. The rationale for using fixeddose combination therapy is to obtain increased blood pressure control by employing two antihypertensive drugs with different modes of action and enhance compliance by using a single tablet. Bilayer tablet is suitable for the sequential release of two drugs in combination, separate, and for sustained release [1, 2].

HHC, directly acting as potent peripheral vasodilator, is widely prescribed in the treatment of hypertension and congestive heart failure by direct relaxation of arteriolar smooth muscle. ISDN is relaxation of vascular smooth muscle and consequent dilatation of peripheral arteries and veins, especially the latter. Dilatation of the veins promotes peripheral pooling of blood and decreases venous return to the heart, thereby reducing left ventricular end-diastolic pressure and pulmonary capillary wedge pressure. The combination consists of an immediate-release layer of hydralazine hydrochloride $25 \mathrm{mg}$ and SR layer of ISDN $40 \mathrm{mg}$ fixed-dose that functions as a nitric oxide enhancer and an antioxidant that helps to prevent tolerance to the prolonged use of nitrate. This combination also balanced after-load and pre-load reduction with a lowering of ventricular filling pressure and systemic and pulmonic vascular resistance. The hemodynamic effects of the combination drug in heart failure include increased cardiac output $[3,4]$. In the present study, according to the U. S. P. 2007 the following constraints were used for the selection of an optimized batch: $\mathrm{Q}_{1}=15 \%$ to $30 \%, \mathrm{Q}_{2}=$ $50 \%$ to $70 \%, Q_{4}=65 \%$ to $85 \%$ and $Q_{6}>75 \%$.

Aim of the present study was the optimization of the SR layer of ISDN $40 \mathrm{mg}$ and compressed with a pre-optimized IR layer of HHC $25 \mathrm{mg}$ to decrease the dosing frequency and develops twice a day formulation.

\section{MATERIALS AND METHODS}

\section{Materials}

HHC was kindly supplied as gift samples by Torrent Pharmaceuticals, Ahmedabad, Gujarat India. ISDN was supplied as gift samples from Cadila Pharmaceuticals Ltd, Ahmadabad, India. Microcrystalline cellulose (MCC), Polyox ${ }^{\text {tm }}$ WSR 303, Ethylcellulose (EC) were procured from Colorcon Asia Pvt. Ltd., Ahmedabad, Gujarat, India. Magnesium stearates, talc, sodium starch glycolate (SSG), croscarmellose sodium (CCS) were purchased from SD Fine Chemicals, Mumbai, India. All other materials and chemicals used were of either pharmaceutical or analytical grade.

\section{Drug-excipients compatibility study}

Drug excipient interaction plays a vital role in achieving the stability of the drug in the dosage form. Fourier transform infrared spectroscopy (FT-IR) was used to study the physical and chemical interactions between drugs and excipients. FT-IR spectra of ISDN and mixtures of drugs with other excipients were obtained by using the FT-IR instrument. (FT-IR-1700, Shimadzu, Kyoto, Japan) [5].

\section{Preliminary screening of polymer for SR layer}

The development of a SR layer containing ISDN $40 \mathrm{mg}$ by selecting ingredients in the appropriate amount and polymer was optimized thereafter. The SR layer of ISDN was prepared by the direct compression method. HPMC K4M, HPMC K100M, polyox ${ }^{\text {tmWSR }} 301$ and Polyox ${ }^{\mathrm{tm}}$ WSR 303 were used in various amounts as shown in table 1. Batch T1 was prepared with HPMC K4M and polyox ${ }^{\text {tm} W S R ~}$ 301. Batch T2 prepared to check the effect of HPMC K4M with

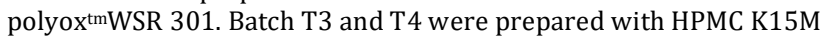
with different grades of polyox ${ }^{\text {tmWSR. Batch } \mathrm{T} 5}$ and $\mathrm{T} 6$ were developed to check the effect of HPMC K100M on different grades of polyox ${ }^{\mathrm{tm}}$ WSR. Prepared layer was evaluated for weight variation, thickness, hardness, friability, disintegration time, drug content, and $\%$ cumulative drug release $[6,7]$. 
Table 1: Preliminary screening of polymer for SR layer

\begin{tabular}{|c|c|c|c|c|c|c|}
\hline Ingredients (mg) & T1 & T2 & T3 & T4 & T5 & T6 \\
\hline ISDN & 40 & 40 & 40 & 40 & 40 & 40 \\
\hline МССРH102 & 88.8 & 88.8 & 88.8 & 88.8 & 88.8 & 88.8 \\
\hline HPMC K4M & 60 & 60 & - & - & - & - \\
\hline HPMC K15M & - & - & 60 & 60 & - & - \\
\hline HPMC K100M & - & - & - & - & 60 & 60 \\
\hline Polyox ${ }^{\text {tmWSR301 }}$ & 60 & - & 60 & - & 60 & - \\
\hline Polyox ${ }^{\text {tmWSR303 }}$ & - & 60 & - & 60 & - & 60 \\
\hline Quinoline yellow & 0.2 & 0.2 & 0.2 & 0.2 & 0.2 & 0.2 \\
\hline Magnesium stearate & 1 & 1 & 1 & 1 & 1 & 1 \\
\hline Total (mg/tablet) & 250 & & & & & \\
\hline
\end{tabular}

\section{Optimization of polymer by using $3^{2}$ full factorial designs}

A $3^{2}$ full factorial design was used for the optimization of the SR layer. The formulation of factorial batches was shown in table 2. Based on preliminary results, the amount of HPMC K100M (X $\left.\mathrm{X}_{1}\right)$ and the amount of polyox ${ }^{\mathrm{tm} W S R} 303\left(\mathrm{X}_{2}\right)$ were chosen as independent variables in $3^{2}$ full factorial designs. In this study, $\mathrm{Q}_{1}\left(\mathrm{Y}_{1}\right), \mathrm{Q}_{2}\left(\mathrm{Y}_{2}\right), \mathrm{Q}_{4}\left(\mathrm{Y}_{3}\right)$ and $\mathrm{Q}_{6}\left(\mathrm{Y}_{4}\right)$ were taken as dependent variables. Multiple linear regression analysis, ANOVA and graphical representation of the influence of factor by contour plots were performed using sigma plot $13.0[8,9]$. The experimental runs and measured responses of $3^{2}$ full factorial design batches of SR layer of ISDN 40 mg were depleted in table 4.

Table 2: Formulation of factorial design batches for the immediate release layer

\begin{tabular}{|c|c|c|c|c|c|c|c|c|c|}
\hline Ingredients (mg) & $\mathbf{F}_{1}$ & $\mathbf{F}_{2}$ & $F_{3}$ & $\mathbf{F}_{4}$ & $F_{5}$ & $F_{6}$ & $\mathbf{F}_{7}$ & $\mathbf{F}_{8}$ & $F_{9}$ \\
\hline ISDN & 40 & 40 & 40 & 40 & 40 & 40 & 40 & 40 & 40 \\
\hline МССРН102 & 88.8 & 78.8 & 68.8 & 78.8 & 68.8 & 58.8 & 68.8 & 58.8 & 48.8 \\
\hline HPMC K100M & 60 & 70 & 80 & 60 & 70 & 80 & 60 & 70 & 80 \\
\hline polyox $^{\mathrm{tm}}$ wsr303 & 60 & 60 & 60 & 70 & 70 & 70 & 80 & 80 & 80 \\
\hline Quinoline yellow & 0.2 & 0.2 & 0.2 & 0.2 & 0.2 & 0.2 & 0.2 & 0.2 & 0.2 \\
\hline Magnesium stearate & 1 & 1 & 1 & 1 & 1 & 1 & 1 & 1 & 1 \\
\hline Total & 250 & 250 & 250 & 250 & 250 & 250 & 250 & 250 & 250 \\
\hline
\end{tabular}

\section{Development of bilayer tablet}

The bilayer tablet was prepared using by direct compression method. In this method IR layer HHN $25 \mathrm{mg}$ and SR layer ISDN 40 mg was were prepared separately and the two layers were compressed together. IR layer of HHN was prepared using a direct compression method. IR layer prepared by using a rotary tablet punching machine by using $8 \mathrm{~mm}$ flat punch on a 12-station rotary tablet machine $[10,11]$. SR layer of ISDN was optimized by using $3^{2}$ full factorial designs and it was prepared using a direct compression method. In this method ISDN, HPMC K100M and polyox WSR 303 were passed through 40\# mesh and mixed well. Other excipients like MCC PH102 and quinoline yellow were added to the above mixture. Finally magnesium stearate was added to the above blend and mixed homogenously. The whole powder blend was collected for compression and $250 \mathrm{mg}$ tablets were compressed using a rotary tablet punching machine by using $8 \mathrm{~mm}$ flat punch on a 12-station rotary tablet machine $[12,13]$.

\section{Evaluation of bilayer tablet}

The prepared tablets were evaluated for thickness, hardness, friability, and disintegration time of the SR layer were measured as described by Nivedithaa VR et al. and Fridrun P et al. [14, 15].

HPLC was used for estimation of HHN and ISDN: The drug concentration was measured according to the reverse-phase highperformance liquid chromatography. Analysis of sample was performed using a cyber lab HPLC system equipped with an LCP-100 pump, cyber lab LC-UV100 UV detector, and RP C18 column (250 × $4.6 \mathrm{~mm}$ ID, particle size $5 \mu$ ) at ambient temperature. The mobile phase used was a mixture of methanol and distilled water $1000 \mathrm{ml}$ containing $0.1 \mathrm{ml}$ TEA each $(60: 40)$. The $\mathrm{pH}$ was adjusted to 6.5 . The flow rate was $1.0 \mathrm{ml}$ per min. The detection was carried out at 215 nm. A calibration curve was plotted for HHN and ISDN. A good linear relationship was observed between the concentration of the drug and the peak area of the drug with a correlation coefficient [16].

Drug content for ISDN: The drug content was carried out by weighing 10 tablets from each batch and calculated the average weight. Then the tablets were triturated and weighed accurately, which was equivalent to $100 \mathrm{mg}$ ISDN. It was dissolved in a $100 \mathrm{ml}$ volumetric flask containing $100 \mathrm{ml}$ of $0.1 \mathrm{~N} \mathrm{HCl}$ and volume was made to $100 \mathrm{ml}$ with solvent. The volumetric flask was shaken using a sonicator for $1 \mathrm{~h}$ and after suitable dilution, with $0.1 \mathrm{~N} \mathrm{HCl}$ the drug content was determined using HPLC at $215 \mathrm{~nm}$.

In vitro drug release study: In vitro release of bilayer tablets was determined using a USP type-II dissolution test apparatus at 100 rpm. The dissolution was studied using $900 \mathrm{ml}$ of simulated gastric fluid $0.1 \mathrm{~N} \mathrm{HCl}$ (without enzyme, $\mathrm{pH} 1.2$ ) for the first $2 \mathrm{~h}$ and followed by a simulated intestinal fluid (without enzyme $\mathrm{pH}$ 6.8) for the remaining $10 \mathrm{~h}$. The temperature was maintained at $37 \pm 0.5^{\circ} \mathrm{C} .5$ ml sample was taken at different time intervals up to $12 \mathrm{~h}$. filter through Whatman filter paper and replaced by an equal volume of dissolution medium sample were suitably diluted and analyzed by HPLC at $215 \mathrm{~nm}$.

Stability study: Optimized batch was packed in aluminum foil and was placed for stability study at $40^{\circ} \mathrm{C} / 75 \% \mathrm{RH}$ for 6 mo. The sample was evaluated after 6 mo for physical parameters and In vitro dissolution. The dissolution profile of the product compared using the similarity factor, $f_{2}$, which was calculated by the following formula.

$$
f_{2}=50 \log \left[\left\{1+\frac{1}{n} \sum_{t=1}^{n}\left(R_{t}-T_{t}\right)^{2}\right\}^{-0.5} x 100\right]
$$

Where a $\log$ is a logarithm to the base $10, \mathrm{n}$ is the number of time points, $\Sigma$ is the summation over all time points, $R_{t}$ is the mean dissolution value of the reference profile at time $t$ and $T_{t}$ is the mean dissolution value of the test profile at the same time point. The USFDA draft guidance document contains more information on the similarity factor $\left(f_{2}\right)$. The value of similarity factor $\left(f_{2}\right)$ between 50 and 100 suggests that the two dissolution profiles are similar $[17,18]$.

\section{RESULTS AND DISCUSSION}

\section{Drug-excipients compatibility study by FT-IR}

Fourier transform infrared spectroscopy (FT-IR) study was used to the physical and chemical interactions between drugs and 
excipients. FT-IR spectra of ISDN with excipients were recorded using $\mathrm{KBr}$ mixing method on the FT-IR instrument. The FT-IR spectra of ISDN and the mixture of drugs with excipient are shown in fig. $1(\mathrm{~A})$ and fig. $1(\mathrm{~B})$. ISDN exhibited peaks due to $\mathrm{C}-\mathrm{O}, \mathrm{O}=\mathrm{NO}_{2}, \mathrm{C}$ -
$\mathrm{H},-\mathrm{CH}_{2}$, and $\mathrm{N}=\mathrm{O}$ stretching as shown in fig. 1 . It was observed that there were no or very minor changes in main drug peaks in the IR spectra of the mixture and pure drug. The FT-IR study revealed no physical or chemical interaction of drugs with excipient [19].

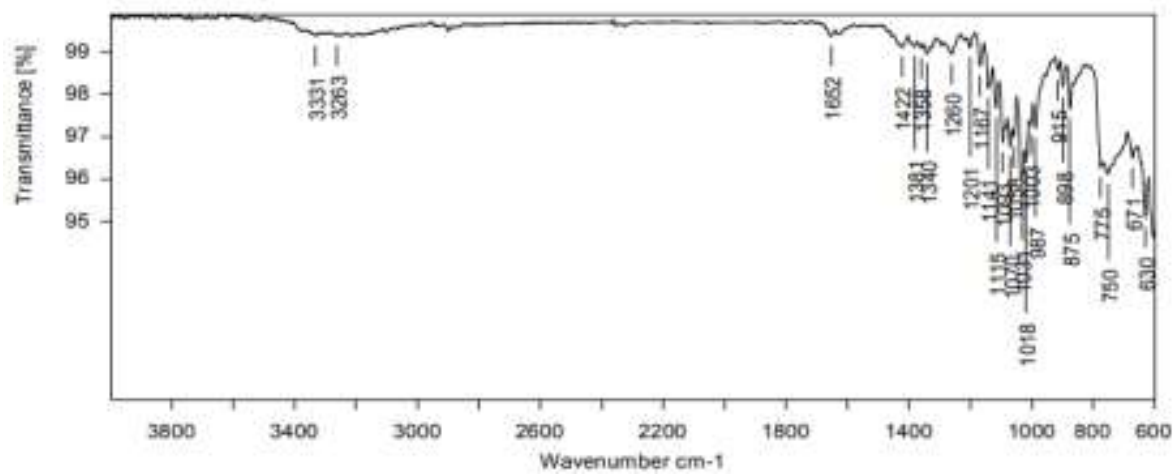

Fig. 1(A): FT-IRof ISDN (Indian pharmacopeia)

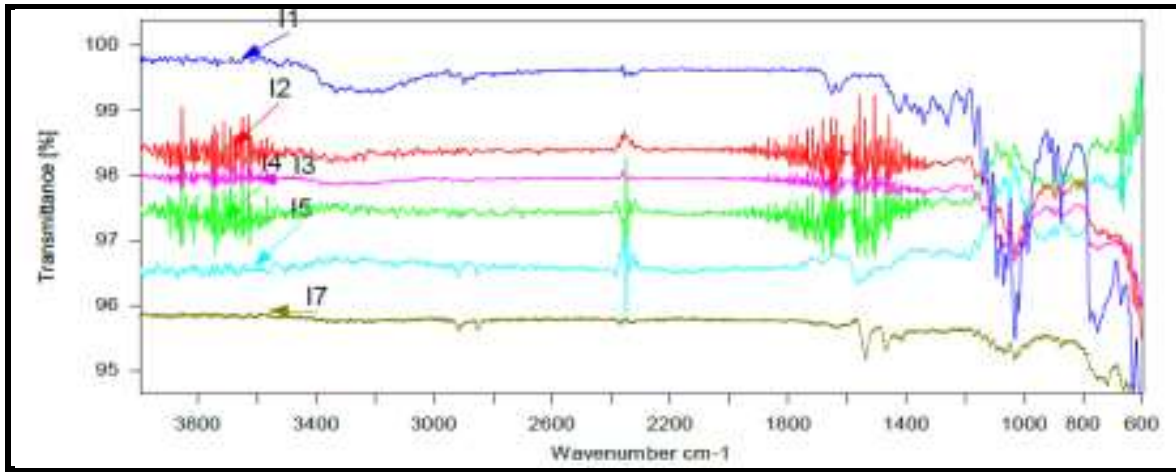

Fig. 1(B): Overlay spectra of ISDNwith all excipients, (I1 = ISDN, I2 = ISDN+MCCPH102, I3 = ISDN+HPMC K100M, I4 = ISDN+polyox WSR303, I4 = ISDN+HPMC K15M, I7 = ISDN+Magnesium Stearate)

Table 3: Preliminary screening of polymer

\begin{tabular}{llllll}
\hline Batch & Hardness $\left(\mathbf{K g} / \mathbf{c m}^{2}\right)$ & Friability $\mathbf{~ ( \% )}$ & $\mathbf{Q}_{\mathbf{1}}$ & $\mathbf{Q}_{\mathbf{2}}$ & $\mathbf{Q}_{\mathbf{4}}$ \\
\hline T1 & $3.30 \pm 0.08$ & $0.40 \pm 0.02$ & $51.09 \pm 2.35$ & $90.80 \pm 1.57$ & $98.80 \pm .57$ \\
T2 & $3.22 \pm 0.06$ & $0.42 \pm 0.05$ & $46.03 \pm 2.85$ & $85.60 \pm 2.47$ \\
T3 & $3.18 \pm 0.03$ & $0.48 \pm 0.03$ & $43.09 \pm 2.35$ & $80.80 \pm 1.57$ \\
T4 & $3.26 \pm 0.02$ & $0.46 \pm 0.05$ & $38.30 \pm 2.85$ & $75.60 \pm 2.47$ & $97.20 \pm 1.51$ \\
T5 & $3.35 \pm 0.04$ & $0.42 \pm 0.04$ & $35.20 \pm 1.38$ & $74.05 \pm 2.48$ & $96.08 \pm 1.57$ \\
T6 & $3.28 \pm 0.01$ & $0.44 \pm 0.07$ & $32.70 \pm 2.67$ & $70.08 \pm 1.41$ & $93.07 \pm 2.32$ \\
\hline
\end{tabular}

*All values are mean $\pm S D,(n=6)$

Table 4: Runs and measured responses of $3^{2}$ factorial design batches

\begin{tabular}{|c|c|c|c|c|c|c|}
\hline $\begin{array}{l}\text { Batch } \\
\text { code }\end{array}$ & $\begin{array}{l}\text { HPMC } \\
\operatorname{K100M}\left(X_{1}\right)\end{array}$ & $\begin{array}{l}\text { POLYOX }^{\mathrm{TM}} \\
\text { WSR303 } ®\left(\mathrm{X}_{2}\right)\end{array}$ & $\mathbf{Q}_{1}\left(\mathrm{Y}_{1}\right)$ & $\mathbf{Q}_{2}\left(\mathrm{Y}_{2}\right)$ & $4 Q_{4}\left(Y_{3}\right)$ & $\mathrm{Q}_{6}\left(\mathrm{Y}_{4}\right)$ \\
\hline$F_{1}$ & -1 & -1 & $32.70 \pm 2.67$ & $70.08 \pm 1.41$ & $90.07 \pm 1.81$ & $99.83 \pm 1.124$ \\
\hline $\mathrm{F}_{2}$ & 0 & -1 & $31.33 \pm 0.57$ & $69.20 \pm 0.29$ & $87.9 \pm 2.33$ & $98.11 \pm 1.32$ \\
\hline $\mathrm{F}_{3}$ & 1 & -1 & $28.62 \pm 0.87$ & $67.23 \pm 014$ & $85.3 \pm 1.55$ & $97.12 \pm 1.544$ \\
\hline $\mathrm{F}_{4}$ & -1 & 0 & $24.66 \pm 0.87$ & $62.34 \pm 0.27$ & $82.5 \pm 1.89$ & $95.18 \pm 1.42$ \\
\hline $\mathrm{F}_{5}$ & 0 & 0 & $21.34 \pm 0.59$ & $57.54 \pm 0.24$ & $79.3 \pm 1.67$ & $94.68 \pm 1.21$ \\
\hline $\mathrm{F}_{6}$ & 1 & 0 & $18.66 \pm 0.32$ & $53.34 \pm 0.17$ & $75.3 \pm 2.57$ & $93.43 \pm 1.04$ \\
\hline $\mathrm{F}_{7}$ & -1 & 1 & $15.33 \pm 0.25$ & $50.54 \pm 0.14$ & $70.4 \pm 2.89$ & $92.78 \pm 1.67$ \\
\hline $\mathrm{F}_{8}$ & 0 & 1 & $14.63 \pm 0.78$ & $48.43 \pm 0.27$ & $69.3 \pm 2.40$ & $91.38 \pm 1.2334$ \\
\hline $\mathrm{F}_{9}$ & 1 & 1 & $13.16 \pm 0.85$ & $46.46 \pm 0.89$ & $68.9 \pm 1.97$ & $90.58 \pm 1.31$ \\
\hline \multicolumn{7}{|c|}{ Factors and the levels in the design } \\
\hline \multicolumn{3}{|c|}{ Independent variables } & $\operatorname{Low}(-1)$ & Medium (0) & High (1) & \\
\hline \multicolumn{3}{|c|}{ HPMC K100M (X } & 60 & 70 & 80 & \\
\hline \multicolumn{3}{|c|}{ POLYOX ${ }^{\mathrm{TM}}$ WSR303 $\left(\mathrm{X}_{2}\right)$} & 60 & 70 & 80 & \\
\hline
\end{tabular}

*All values are mean $\pm S D,(n=6)$ 
Table 5: Evaluation of $3^{2}$ factorial design batches

\begin{tabular}{|c|c|c|c|c|c|c|}
\hline Batch & Hausner's ratio & Angle of repose $(\theta)$ & Weight variation (mg) & Thickness (mm) & Friability \% & Drug content \% \\
\hline $\mathrm{F}_{1}$ & $1.15 \pm 0.05$ & $23.54 \pm 0.02$ & $249.40 \pm 0.18$ & $4.22 \pm 0.03$ & $0.73 \pm 0.03$ & $99.40 \pm 0.36$ \\
\hline $\mathrm{F}_{2}$ & $1.14 \pm 0.01$ & $22.36 \pm 0.09$ & $250.60 \pm 0.07$ & $4.57 \pm 0.04$ & $0.68 \pm 0.15$ & $99.45 \pm 1.18$ \\
\hline $\mathrm{F}_{3}$ & $1.14 \pm 0.05$ & $22.38 \pm 0.09$ & $251.83 \pm 1.07$ & $4.36 \pm 0.04$ & $0.73 \pm 0.04$ & $99.86 \pm 1.52$ \\
\hline $\mathrm{F}_{4}$ & $1.16 \pm 0.05$ & $23.82 \pm 0.07$ & $250.50 \pm 0.56$ & $4.30 \pm 0.05$ & $0.53 \pm 0.05$ & $98.13 \pm 2.23$ \\
\hline $\mathrm{F}_{5}$ & $1.18 \pm 0.07$ & $25.38 \pm 0.06$ & $250.70 \pm 0.57$ & $4.28 \pm 0.07$ & $0.53 \pm 0.03$ & $99.33 \pm 1.52$ \\
\hline $\mathrm{F}_{6}$ & $1.17 \pm 0.01$ & $24.80 \pm 0.05$ & $250.90 \pm 0.78$ & $4.41 \pm 0.09$ & $0.44 \pm 0.017$ & $99.26 \pm 1.32$ \\
\hline $\mathrm{F}_{7}$ & $1.16 \pm 0.02$ & $23.81 \pm 0.03$ & $251.43 \pm 1.55$ & $4.48 \pm 0.02$ & $0.62 \pm 0.02$ & $98.60 \pm 1.87$ \\
\hline $\mathrm{F}_{8}$ & $1.16 \pm 0.02$ & $23.86 \pm 0.31$ & $250.45 \pm 0.67$ & $4.42 \pm 0.01$ & $0.81 \pm 0.45$ & $99.70 \pm 0.71$ \\
\hline $\mathrm{F}_{9}$ & $1.17 \pm 0.01$ & $24.85 \pm 0.07$ & $250.70 \pm 0.56$ & $4.25 \pm 0.32$ & $0.59 \pm 0.45$ & $99.57 \pm 1.47$ \\
\hline
\end{tabular}

*All values are mean $\pm S D,(n=6)$

\section{Preliminary screening of polymers for SR layer}

The batches T1 to T6 were prepared to achieve an optimized concentration of polymer and the most efficacious one among incorporated to prepare SR layer of ISDN $40 \mathrm{mg}$, as shown by table 1 . Preliminary trial batches results were shown in table 3 . Batch T1 containing HPMC K4M and Polyox ${ }^{\mathrm{tm}}$ WSR 301 showed $51.09 \pm 2.35 \%$ drug release at $1 \mathrm{~h}$. Batch T2 and batch T3 were shown $46.03 \pm 2.85 \%$ and $43.09 \pm 2.35 \%$ drug release in $1 \mathrm{~h}$, respectively. While batch T4 and $\mathrm{T} 5$ give, $75.60 \pm 2.48 \%$ and $74.05 \pm 2.48 \%$ release in $2 \mathrm{~h}$. Batch T6 contains HPMC K100M and Polyox ${ }^{\text {tm }}$ WSR 303 that shows $32.70 \pm 2.67$ $\%$ and $70.08 \pm 1.41 \%$ drug release at $1 \mathrm{~h}$ and $2 \mathrm{~h}$, respectively. Hence, further trials were carried out by using a combination of HPMC K100M and polyoxtmWSR 303 to understand their effect and optimize the concentration of both for the desired release profile [20].

\section{$3^{2}$ full factorial design model evaluation}

A statistical model incorporating interactive and polynomial terms used to evaluate the responses:

$\mathrm{Y}=\mathrm{b}_{0+} \mathrm{b}_{1} \mathrm{X}_{1}+\mathrm{b}_{2} \mathrm{X}_{2}+\mathrm{b}_{11} \mathrm{X}_{1}{ }^{2}+\mathrm{b}_{22} \mathrm{X}_{2}{ }^{2}+\mathrm{b}_{12} \mathrm{X}_{1} \mathrm{X}_{2}$
Where $\mathrm{Y}$ is the dependent variable, $b_{0}$ is the arithmetic mean response of the 9 runs and any bi is the estimated coefficients for the related factor $X_{i}$. The main effects $\left(X_{1}\right.$ and $\left.X_{2}\right)$ represent the average result of changing one factor at a time from its low to high value. The polynomial terms $\left(\mathrm{X}_{1}{ }^{2}\right.$ and $\left.\mathrm{X}_{2}{ }^{2}\right)$ are included to investigate nonlinearity. The interaction term " $\mathrm{X}_{1} \mathrm{X}_{2}$ " shows how the response changes when the two factors change simultaneously. Evaluation data for SR layer of ISDN $40 \mathrm{mg}$ were presented in table 4 and table 5 . The fitted equations relating the responses that are, $Q_{1}\left(Y_{1}\right), \% Q_{2}$ $\left(\mathrm{Y}_{2}\right), \mathrm{Q}_{4}\left(\mathrm{Y}_{3}\right)$ and \% $\mathrm{Q}_{6}\left(\mathrm{Y}_{4}\right)$ were to the transformed factor are shown in table 7. The polynomial equation used to conclude after considering the magnitude of coefficient and mathematical sign it carries (i.e. positive or negative). The results of ANOVA suggested that calculated $\mathrm{F}$ values for $\mathrm{Q}_{1}, \mathrm{Q}_{2}, \mathrm{Q}_{4}$, and $\mathrm{Q}_{6}$ were $084.583,038.188$, 057.719 , and 118.396 , respectively, shown in table 6 . Tabulated $F$ value was found to be 9.013 at $\alpha=0.05$. Calculated $F$ values are greater than tabulated for all dependent variables. Therefore, the factors selected have shown significant effects. From the results of multiple regression analysis, it was found that all factors had a statistically significant influence on all dependent variables as $\mathrm{p}<0.05[21,22]$.

Table 6: Results of the ANOVA for dependent variables

\begin{tabular}{|c|c|c|c|c|c|}
\hline Source of variation & DF & SS & MS & F value & P value \\
\hline \multicolumn{6}{|l|}{$\mathrm{Q}_{1}^{*}$} \\
\hline Regression & 5 & 437.224 & 087.445 & 084.583 & 0.002 \\
\hline Residual & 3 & 003.102 & 001.034 & & \\
\hline Total & 8 & 440.325 & 055.041 & & \\
\hline \multicolumn{6}{|l|}{$\mathrm{Q}_{2} \#$} \\
\hline Regression & 5 & 666.154 & 133.231 & 038.188 & 0.006 \\
\hline Residual & 3 & 010.467 & 003.489 & & \\
\hline Total & 8 & 676.621 & 084.578 & & \\
\hline \multicolumn{6}{|l|}{$\mathrm{Q}_{4} @$} \\
\hline Regression & 5 & 528.985 & 105.797 & 057.719 & 0.004 \\
\hline Residual & 3 & 005.499 & 001.833 & & \\
\hline Total & 8 & 534.484 & 066.810 & & \\
\hline \multicolumn{6}{|l|}{$\mathrm{Q}_{6} \$$} \\
\hline Regression & 5 & 76.869 & 15.374 & 118.396 & 0.001 \\
\hline Residual & 3 & 0.390 & 0.130 & & \\
\hline Total & 8 & 77.259 & 9.657 & & \\
\hline
\end{tabular}

${ }^{*} \mathrm{Q}_{1}=\%$ cumulative drug releases at $1 \mathrm{~h}, \# \mathrm{Q}_{2}=\%$ cumulative drug releases at $2 \mathrm{~h}, @ \mathrm{Q}_{4}=\%$ cumulative drug releases at $4 \mathrm{~h}, \$ \mathrm{Q}_{6}=\%$ cumulative drug releases at $6 \mathrm{~h}$

Table 7: Summary of regression output of factors for measured responses

\begin{tabular}{|c|c|c|c|c|c|c|c|c|}
\hline \multirow[t]{2}{*}{ Responses } & \multirow[t]{2}{*}{ Model } & \multicolumn{7}{|c|}{ Coefficient of regression parameters } \\
\hline & & $\mathbf{b}_{\mathbf{0}}$ & $\mathbf{b}_{1}$ & $\mathbf{b}_{2}$ & $\mathbf{b}_{11}$ & $\mathbf{b}_{22}$ & $\mathbf{b}_{12}$ & $\mathbf{R}^{\mathbf{2}}$ \\
\hline \multirow[t]{2}{*}{$\mathrm{Q}_{1}$} & Full & 21.717 & 2.042 & 8.255 & 0.245 & 1.075 & 0.478 & 0.993 \\
\hline & Reduced & 21.717 & 2.042 & 8.255 & - & - & - & \\
\hline \multirow[t]{2}{*}{$\mathrm{Q}_{2}$} & Full & 57.779 & 2.655 & 10.180 & 0.0583 & 0.917 & 0.308 & 0.959 \\
\hline & Reduced & 57.779 & 2.655 & 10.180 & - & - & - & \\
\hline \multirow[t]{2}{*}{$\mathrm{Q}_{4}$} & Full & 79.143 & 2.248 & 9.090 & 0.105 & 0.400 & 0.797 & 0.990 \\
\hline & Reduced & 79.143 & 2.248 & 9.090 & - & - & - & \\
\hline \multirow[t]{2}{*}{$\mathrm{Q}_{6}$} & Full & 94.366 & 1.110 & 3.387 & 0.0967 & 0.537 & 0.127 & 0.995 \\
\hline & Reduced & 94.366 & 1.110 & 3.387 & - & - & - & \\
\hline
\end{tabular}

${ }^{*} \mathrm{Q}_{1}=\%$ cumulative drug releases at $1 \mathrm{~h}, \# \mathrm{Q}_{2}=\%$ cumulative drug releases at $2 \mathrm{~h}, \mathrm{Q}_{4}=\%$ cumulative drug releases at $4 \mathrm{~h}, \$ \mathrm{Q}_{6}=\%$ cumulative drug releases at $6 \mathrm{~h}$ 
Full and reduced model for $\mathbf{Q}_{1}$

$$
\begin{gathered}
\mathrm{Q}_{1}=21.717-\left(2.042 * \mathrm{X}_{1}\right)-\left(8.255 * \mathrm{X}_{2}\right)-\left(0.245 * \mathrm{X}_{1}{ }^{2}\right)+(1.075 * \\
\left.\mathrm{X}_{2}{ }^{2}\right)+\left(0.478 * \mathrm{X}_{1} \mathrm{X}_{2}\right)
\end{gathered}
$$

In this analysis, $Q_{1}$ ranges were observed between $13.16 \pm 0.85 \%$ to $32.7 \pm 2.67 \%$. Based on the analysis of variance (ANOVA) the result showed that the developed linear model was highly significant, as was evident from a very low probability value 0.002 . The value of $\mathrm{R}^{2}$ was found to be 0.993 . The plot of the observed value of $Q_{1}$ versus the predicted value of $\mathrm{Q}_{1}$ (fig. $3 \mathrm{~B}$ ) shows a straight line. Therefore, it concluded that the equation has good predictive ability. From the 3D plot (fig. 3A) and regression coefficient values of factors, it was

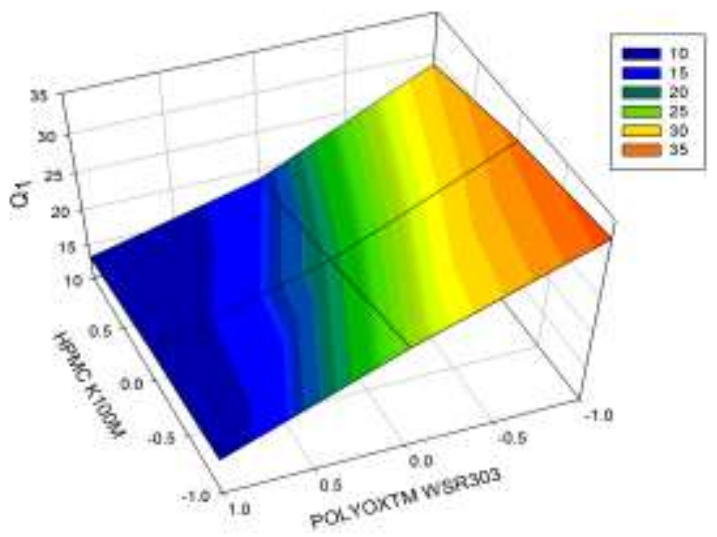

A concluded that when the amount of polymer was increased, drug releases was decrease. The polyether chains of polyox ${ }^{\mathrm{tm} W S R} 303$ can form strong hydrogen bonds with water; polyox ${ }^{\text {tmWSR303 upon }}$ exposure to water or gastric juices, they hydrate and swell rapidly to form hydrogels. Therefore, polyox ${ }^{\text {tm }}$ WSR 303 was given a more significant effect on drug releases. Interaction and nonlinearity was not observed. For $\mathrm{Q}_{1}$, the significance levels of the coefficients $\mathrm{b}_{11}, \mathrm{~b}_{22}$ and $\mathrm{b}_{12}$ were found to be $\mathrm{P}=0.756,0.232$, and 0.417 , respectively, so they were omitted from the full model to generate a reduced model. The coefficients $\mathrm{b}_{1}$, and $\mathrm{b}_{2}$ were found to be significant at $\mathrm{P}<0.05$; hence, it was retained in the reduced model. The reduced model for $\mathrm{Q}_{1} \mathrm{Q}_{1}=21.717-\left(2.042 * \mathrm{X}_{1}\right)-\left(8.255 * \mathrm{X}_{2}\right)$

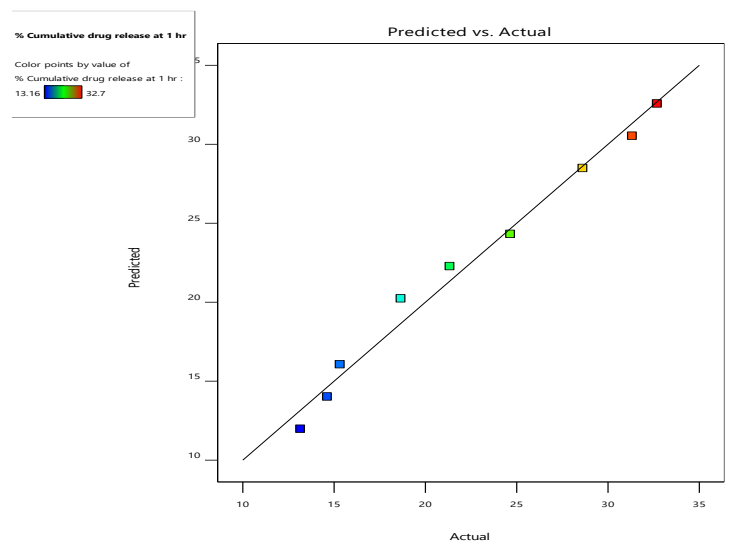

B

Fig. 2: (A) 3D plot showing the effect of HPMC K100M and polyox ${ }^{\text {tm }}$ WSR303 on $\% Q_{1}$ (B) Predicted Vs actual value of $Q_{1}$

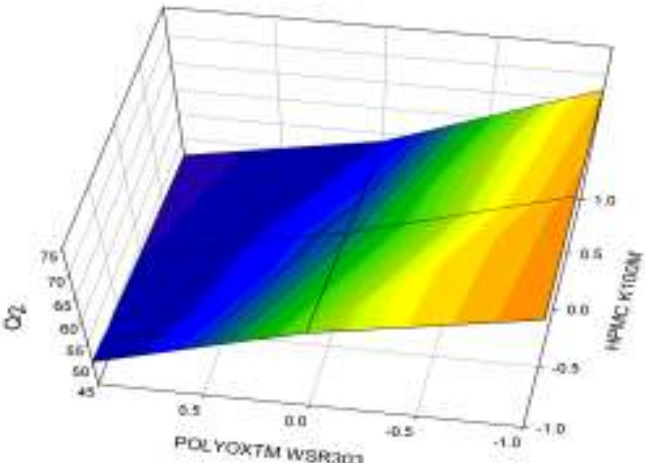

A
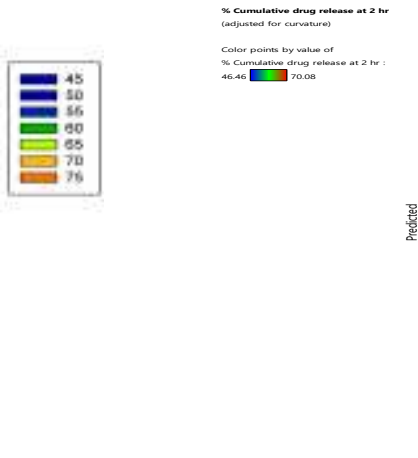

Fig. 3: (A) 3D plot showing the effect of HPMC K100M and polyox ${ }^{\text {tm }}$ wsr303 on $\% Q_{2}$ (B) Predicted Vs actual value of $Q_{2}$
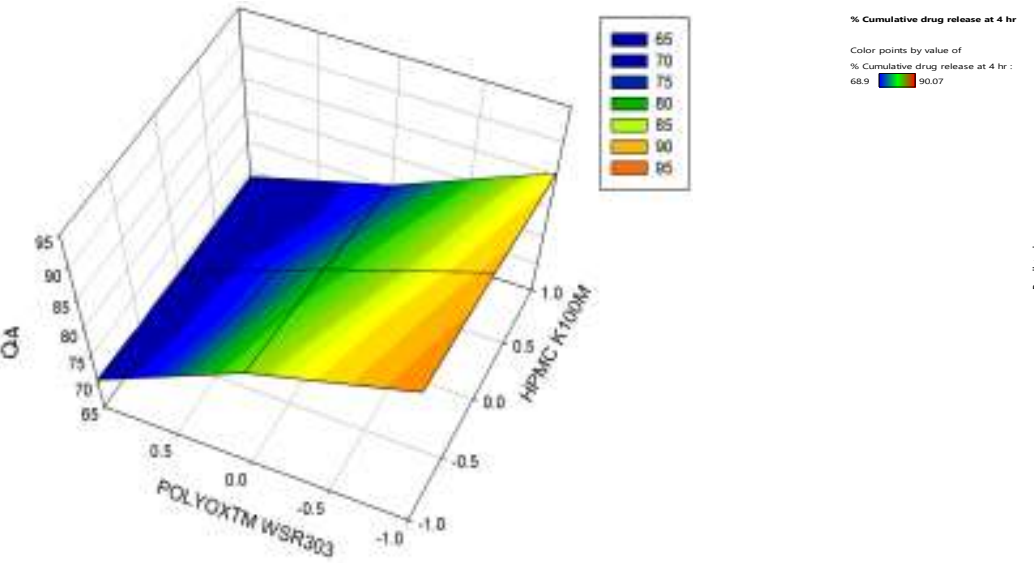

A

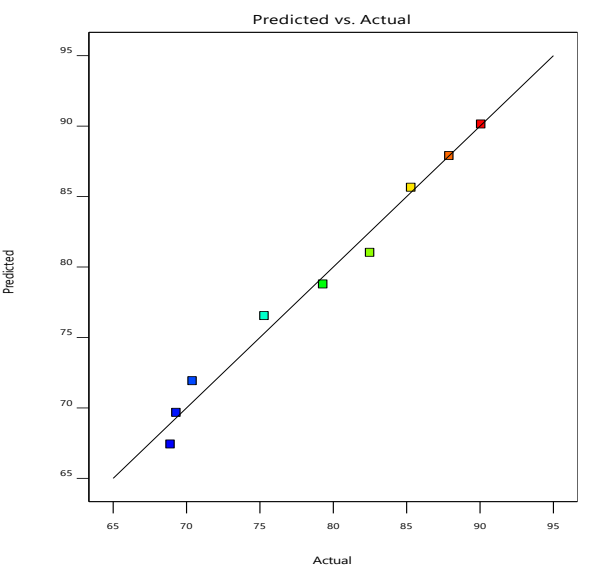

Fig. 4 (A): 3D plot showing the effect of HPMC K100M and POLYOX ${ }^{\mathrm{TM}}$ WSR303 on $Q_{4}$ (B) Predicted Vs actual value of $Q_{4}$ 
Full and reduced model for $\mathbf{Q}_{4}$

$$
\begin{gathered}
\mathrm{Q}_{4}=79.143-\left(2.248 * \mathrm{X}_{1}\right)-\left(9.090 * \mathrm{X}_{2}\right)-\left(0.105 * \mathrm{X}_{1}{ }^{2}\right)-(0.400 * \\
\left.\mathrm{X}_{2}{ }^{2}\right)+\left(0.797 * \mathrm{X}_{1} \mathrm{X}_{2}\right)
\end{gathered}
$$

In this analysis, the $\mathrm{Q}_{4}$ ranges were observed between $68.90 \pm 1.97 \%$ to $90.70 \pm 1.81 \%$. The value of $\mathrm{R}^{2}$ was found to be 0.985 . ANOVA analysis indicates that the developed linear model was significant, and it shows a very low probability value of 0.004 . The plot of the observed value of $\mathrm{Q}_{4}$ versus the predicted value of $\mathrm{Q}_{4}$ (fig. 4B) shows a straight line. From the 3D plot (fig. 4A) and the regression coefficient values of factors, it

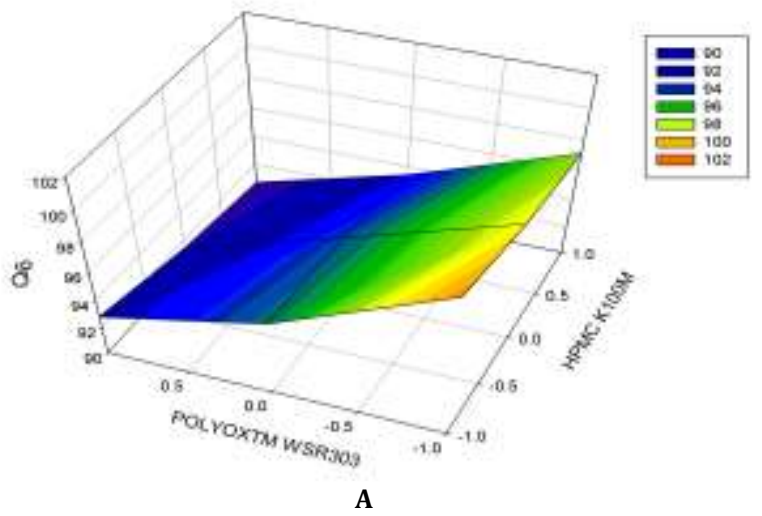

was concluded that when Polyox ${ }^{\text {tm }}$ WSR303 amount was increased $Q_{4}$ more decrease compared to the HPMC K100M. It was found that higher polymeric content in the matrix decreased the release rate of the drug. Interaction and nonlinearity was not observed. For $\mathrm{Q}_{4}$, the significance levels of the coefficients $b_{11}, b_{22}$, and $b_{12}$ were found to be $\mathrm{P}=0.920,0.704$, and 0.324 , respectively, so they were omitted from the full model to generate a reduced model [22]. The coefficients $b_{1}$ ,and $\mathrm{b}_{2}$ were found to be significant at $\mathrm{P}<0.05$; hence, it was retained in the reduced model. The reduced model for $Q_{4} Q_{4}=79.143-\left(2.248 * X_{1}\right)$ $\left(9.090 * \mathrm{X}_{2}\right)$

Fig. 5: (A) 3D plot showing the effect of HPMC K100M and Polyox ${ }^{\text {tm }}$ WSR303 on $Q_{6}$ (B) Predicted Vs actual value of $Q_{6}$

\section{Full and reduced model for $\mathbf{Q}_{6}$}

$$
\begin{gathered}
Q_{6}=94.366-\left(1.110 * X_{1}\right)-\left(3.387 * X_{2}\right)+\left(0.0967 * X_{1}^{2}\right)+(0.537 * \\
\left.X_{2}^{2}\right)+\left(0.127 * X_{1} X_{2}\right)
\end{gathered}
$$

In this analysis, the $\mathrm{Q}_{6}$ ranges were observed between $90.58 \pm 1.34 \%$ to $99.83 \pm 1.12 \%$. Based on the analysis of variance (ANOVA) the result showed that the developed linear model was highly significant, as was evident from a very low probability value 0.001 . The value of $\mathrm{R}^{2}$ was found to be 0.995 . The plot of the observed value of $\mathrm{Q}_{6}$ versus the predicted value of $\mathrm{Q}_{6}$ (fig. $5 \mathrm{~B}$ ) shows a straight line. Therefore, it concluded that the equation has good predictive ability. Interaction and nonlinearity was not observed. From the 3D plot (fig. 5A) and regression coefficient values of factors, it was concluded that when the amount of polymer was increased, drug releases was decreased. The results also indicated that Polyox ${ }^{\mathrm{tm}}$ WSR 303 was given a more significant effect on drug releases. For $\mathrm{Q}_{6}$, the significance levels of the coefficients $b_{11}, b_{22}$, and $b_{12}$ were found to be $P=0.730,0.126$ and 0.530 respectively, so they were omitted from the full model to generate a reduced model. The coefficients $b_{1}$, and $b_{2}$ were found to be significant at $\mathrm{P}<0.05$; hence, it was retained in the reduced model

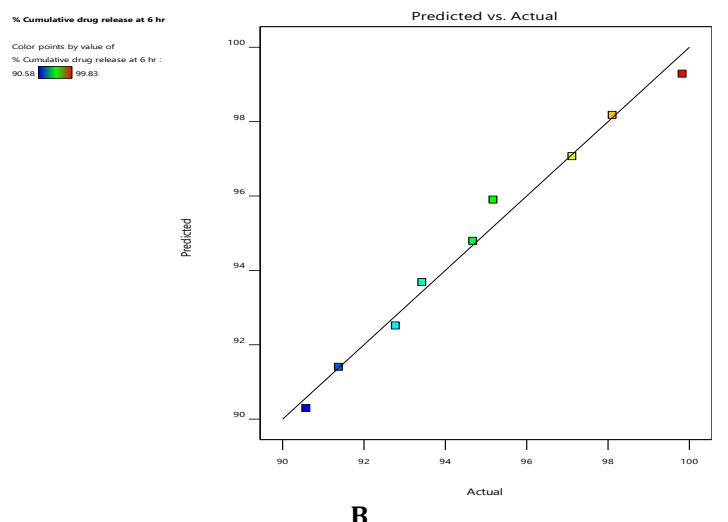

B

$$
Q_{6}=94.366-\left(1.110 * X_{1}\right)-\left(3.387 * X_{2}\right)
$$

\section{Search for the selection of optimized formulation}

The optimization of the SR layer of ISDN $40 \mathrm{mg}$ by numerical optimization. According to the U. S. P. 2007 the following constraints were used for the selection of an optimized batch: $Q_{1}=15 \%$ to $30 \%$, $\mathrm{Q}_{2}=50 \%$ to $70 \%, \mathrm{Q}_{4}=65 \%$ to $85 \%$ and $\mathrm{Q}_{6}>75 \%$. Further, the optimized SR layer was demarcated in the design space (overlay plot) shown in fig. 6 . To validate the evolved mathematical models, a check-point was selected from its desirability value 1 . Check-point batch CP1 was prepared and evaluated. The observed and predicted values for batch CP1 as shown in table 8. A good correlation was found between observed and predicted values. Hence, it was concluding that the evolved models might be used for the theoretical prediction of responses within the factor space. Optimized SR layer gives a $93.40 \pm 1.29 \%$ drug release within $6 \mathrm{~h}$. It was kept for stability study and in vitro release profile at initial and after 6 mo was compared using similarity factor, $\mathrm{f}_{2}$, value that was found to be $93.078 \%$ for SR layer of ISDN. There is no significant difference in the similarity factor.
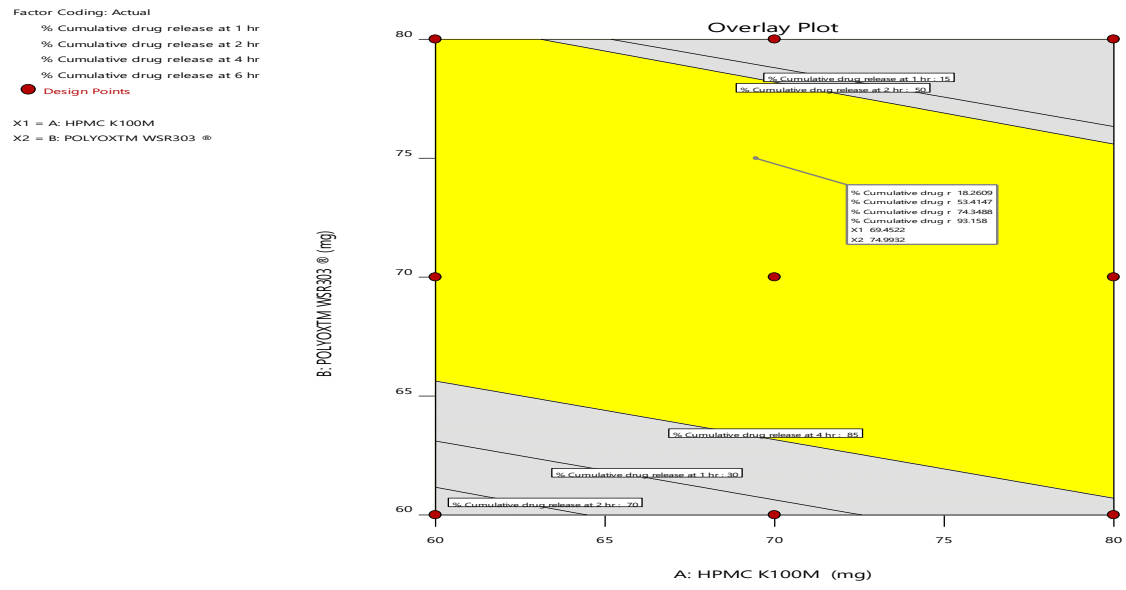

Fig. 6: Overlay plot depicting yellow color region design space and flagged point as the optimized SR layer of ISDN $40 \mathrm{mg}$ 
Table 8: Formulation and evaluation of check point batches

\begin{tabular}{|c|c|c|c|c|c|}
\hline \multicolumn{6}{|c|}{ Formulation of check point batches } \\
\hline \multirow[t]{3}{*}{ Batch Code } & Variable Level & & & & \multirow[b]{3}{*}{$\mathrm{X}_{2}(\mathrm{mg})$} \\
\hline & Coded Value & & Actual Value & & \\
\hline & $\mathrm{X}_{1}$ & $\mathrm{X}_{2}$ & $\mathrm{X}_{1}(\mathrm{mg})$ & & \\
\hline CP1 & 0 & 1.11 & 70.00 & & 77.94 \\
\hline \multicolumn{6}{|c|}{ Evaluation of check point batches and comparison with predicted value } \\
\hline \multicolumn{2}{|c|}{ Parameter } & \multicolumn{2}{|c|}{ Actual value } & \multicolumn{2}{|c|}{ Predicted value } \\
\hline \multicolumn{2}{|c|}{$\%$ Cumulative drug releases at $1 \mathrm{~h}\left(\mathrm{Q}_{1}\right)$} & \multicolumn{2}{|c|}{$14.87 \pm 0.36$} & \multicolumn{2}{|c|}{15.708} \\
\hline \multicolumn{2}{|c|}{$\%$ Cumulative drug release at $2 \mathrm{~h}\left(\mathrm{Q}_{2}\right)$} & \multicolumn{2}{|c|}{$52.40 \pm 1.24$} & \multicolumn{2}{|l|}{50.259} \\
\hline \multicolumn{2}{|c|}{$\%$ Cumulative drug release at $4 \mathrm{~h}\left(\mathrm{Q}_{4}\right.$} & \multicolumn{2}{|c|}{$79.40 \pm 0.68$} & \multicolumn{2}{|l|}{71.531} \\
\hline \multicolumn{2}{|c|}{$\%$ Cumulative drug release at $6 \mathrm{~h}\left(\mathrm{Q}_{6}\right)$} & \multicolumn{2}{|c|}{$93.40 \pm 1.29$} & \multicolumn{2}{|l|}{92.096} \\
\hline
\end{tabular}

$(n=6)$

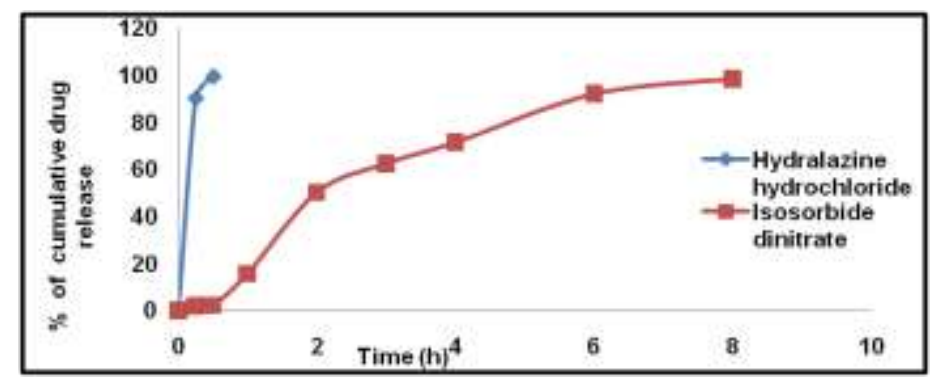

Fig. 7: In vitro drug release study of bilayer antihypertensive tablet

\section{Evaluation of bilayer tablets}

Finally, the optimized IR layer HHC $25 \mathrm{mg}$ and SR layer ISDN $40 \mathrm{mg}$ were prepared separately and two layers compressed together. In vitro Release of the bilayer tablet was shown in fig. 7. HHC gives $100 \%$ drug release in $30 \mathrm{~min}$. While ISDN gives $91.67 \pm 0.68 \%$ in a simulated intestinal fluid in $6 \mathrm{~h}$.

\section{CONCLUSION}

The present investigation was to formulate, evaluate, and optimize SR layer containing ISDN $40 \mathrm{mg}$ in a bilayer tablet. There was no Drug-excipient interaction in the FT-IR study. From the results of preliminary studies, HPMC K100M $\left(\mathrm{X}_{1}\right)$ and the amount of Polyox ${ }^{\text {tm }}$ WSR303 $\left(\mathrm{X}_{2}\right)$ was chosen as independent variables in $3^{2}$ full factorial design. While $\mathrm{Q}_{1}\left(\mathrm{Y}_{1}\right), \mathrm{Q}_{2}\left(\mathrm{Y}_{2}\right), \mathrm{Q}_{4}\left(\mathrm{Y}_{3}\right)$ and $\mathrm{Q}_{6}\left(\mathrm{Y}_{4}\right)$, were taken as dependent variables. The effect of independent variables on dependent variables was studied by analyzing the response surface plot and polynomial equation. Optimization of the SR layer of ISDN was performed by the overlay plot. A checkpoint batch was designed according to the results of the desirability value and evaluated for all the parameters. The results of the comparison of predicted response and obtained responses were found in good agreement. The formulation was found to be stable during accelerated stability study. SR of ISDN was helped to prevent tolerance to the prolonged use of nitrate. Finally, optimize layers of HHC and optimize layer of ISDN were prepared separately, and the two layers compressed together. This fixed-dose two times a day therapy has functioned as a nitric oxide enhancer and an antioxidant that helps to prevent tolerance to the prolonged use of nitrate.

\section{FUNDING}

Nil

\section{AUTHORS CONTRIBUTIONS}

All the authors have contributed equally.

\section{CONFLICT OF INTERESTS}

Declared none

\section{REFERENCES}

1. Jamie K, Rachael F, Katherine L, Tucker, Richard J, McManus. New approaches in hypertension management: a review of current and developing technologies and their potential impact on hypertension care. Curr Hypertens Rep 2019;21:1-8.

2. Taddei S. Combination therapy in hypertension: what are the best options according to clinical pharmacology principles and controlled clinical trial evidence? Am J Cardiovasc Drugs 2015;15:185-94.

3. Carmody MS, Anderson JR. BiDil (isosorbide dinitrate and hydralazine): a new fixed-dose combination of two older medications for the treatment of heart failure in black patients. Cardiol Rev 2007;15:46-53.

4. Cheng JW. A review of isosorbide dinitrate and hydralazine in the management of heart failure in black patients, with a focus on a new fixed-dose combination. Clin Ther 2006;28:666-78.

5. Momin S, Khan S, Ghadage D, Yadav A, Wagh A. Formulation and evaluation of bilayer tablets of propranolol hydrochloride. J Drug Delivery Ther 2017;7:50-7.

6. D Radhika, A Mohaideen, Manoj KR, Bhanu PS, Jahan Nur, Rahman H. Development of bi-layer tablets for immediate and controlled release of allicin. Int J Curr Pharm Res 2017;9:153-60.

7. Harika R, S Dineshmohan, Alluri Ramesh, VRM Gupta. Formulation and in vitro evaluation of bilayer tablets of nebivolol hydrochloride and nateglinide for the treatment of diabetes and hypertension. J Drug Delivery 2015:1-14. DOI:10.1155/2015/827859

8. SN Politis, P Colombo, G Colombo, DM Rekkas. Design of experiments (DoE) in pharmaceutical development. Drug Dev Ind Pharm 2017;43:889-901.

9. Kamble S, Poul B, Udapurkar P. Bilayer tablet of tramadol and gabapentin for combination pharmacotherapy of neuropathic pain: development and characterization. Int J Appl Pharm 2018;10:100-7.

10. Kulkarni AMT, Aloorkar N. Application of novel natural polymer for controlling the release of fenoverine from controlled release matrix tablets. Int J Appl Pharm 2017;9:1-9.

11. Karad BB, Shinde AD. Formulation and evaluation of an immediate-release tablet of levonorgestrel. Indo Am J Pharm Res 2017;7:471-9.

12. Kumar GH, Jaganathan K, Kumar RS, Perumal P. Formulation and in vitro evaluation of bilayer floating tablets of metformin hydrochloride and sitagliptin phosphate. Int J Adv Pharm 2012;2:64-81.

13. Sarfaraz Md, Reddy PKC, Udupi RH, Doddayya H. Formulation and in vitro evaluation of bilayer floating tablets of tramadol hydrochloride. Int J Drug Dev Res 2012;4:335-47. 
14. Nivedithaa VR, Maanvizhi S. Formulation and evaluation of immediate-release combination tablet for cardiovascular diseases. Res J Life Sci Bioinf Pharm Chem Sci 2018;4:176-90.

15. Fridrun P. Theoretical and experimental investigations into the delamination tendencies of bilayer tablets. Int J Pharm 2011;408:102-12.

16. Neelima K, Prasad YR. Analytical method development and validation for simultaneous estimation of Hydralazine, Isosorbide dinitrate in bulk and tablet formulation by RPHPLC. Int J Pharm Sci Res 2014;5:1290-4.

17. Kamble SR, Poul BN, Udapurkar PP. Fabrication and evaluation of bilayer floating tablet containing conventional ibuprofen and modified-release pregabalin for combination pharmacotherapy of neuropathic pain. Asian J Pharm 2016;10:290-9.

18. Saripilli R, Kudamala S, Murthy KVR. Development, formulation and evaluation of a bilayer gastric retentive floating tablets of ranitidine $\mathrm{HCl}$ and clarithromycin using natural polymers. Int J Pharm Pharm Sci 2017; 9:164-77.

19. R Mazzeo, S Prati, M Quaranta, E Joseph, E Kendix, M Galeotti. Attenuated total reflection micro FTIR characterization of pigment-binder interaction in reconstructed paint films. Anal Bioanal Chem 2008;392:65-76.

20. Dnyaneshwar DG, Deshmukh MT, Solunke RS, Shete RV. Formulation and evaluation of antihypertensive bilayer tablets. Int J Pharm Sci Res 2019;10:4760-75.

21. Bolton S, Bon C. Pharmaceutical statistics: practical and clinical applications. $5^{\text {th }}$ ed. Informa Healthcare; 2005. p. 472-93.

22. Mandlik SK, Dandgavhal HP. Enhancement of skin permeability of econazole nitrate using novel flexisomal nanocarriers by implementing quality by design (QbsD) approach. Int J Appl Pharm 2019;12:123-33. 